\title{
The Effects of Pregnancy and Feeding on the Insulin and Glucose Concentrations in Blood of Ewes in Late Pregnancy
}

\author{
By Helgi Sigurdsson
}

\begin{abstract}
Sigurdsson, $\mathrm{H}$ : The effects of pregnancy and feeding on the insulin and glucose concentrations in blood of ewes in late pregnancy. Acta vet. scand. 1988, 29, 401405. - In 8 experimental ewes on normal diet the influence of pregnancy and feeding on insulin and glucose in the blood was studied. A reduction in insulin concentration was found as pregnancy advanced. Blood glucose fluctuated, but during late pregnancy the blood glucose level was significantly lower in twin-pregnant ewes than in ewes pregnant with 1 fetus. No increase in insulin concentration was demonstrated in twin-pregnant ewes after feeding, on the contrary an increase was found in ewes pregnant with 1 fetus. A limited effect of feeding on the glucose concentration was observed, especially compared to the reference range. A positive correlation was obtained between the concentration of glucose and insulin in the blood.
\end{abstract}

sheep; twins; metabolism; feed-induced effect.

\section{Introduction}

The chemical composition of the blood is under considerable homeostatic control, which is mediated by hormonal secretions and feed-back mechanisms. The concentration of the various components are thus maintained within fairly narrow limits, but several factors affects this equilibrium such as age, sex, feeding and pregnancy.

Hormonal regulation of glucose homeostatis is central in the metabolic regulation and it appears that most of the hormonal alterations observed in ruminants in different situations can be related to the need for maintenance of glucose homeostasis.

The balance between food and requirement is a central element in the pathogenesis of pregnancy disease, where the growth of the fetuses in late pregnancy imposes additional demands on nutritional intake of the pregnant ewe. Disorder of glucose homeostasis appear to play a role in the pathogenesis of the disease (McClymont \& Setchell 1955). Most studies of the effects of feeding on glucose homeostasis in ewes have been carried out in non-pregnant animals. The purpose of the present work was to study the influence of pregnancy, number of fetuses and feeding on insulin and glucose concentration in the blood of pregnant ewes, especially during late pregnancy.

\section{Materials and methods Animals}

Eight pregnant Marsk-Texel crossbred ewes were used, of which 5 were twin-pregnant (no. 51, 52, 53, 54, 55) and 3 (no. 56, 57, 58) pregnant with 1 fetus 
The ewes were fed indoors from 60 days gestation with $12-14 \mathrm{~kg}$ hay the first 2 months, but in the last month the ewes were fed with $18 \mathrm{~kg}$ hay and up to $1400 \mathrm{~g}$ concentrates (15\% crude protein) daily. Blood samples were drawn twice weekly before the morning feeding.

During late pregnancy (at about 100 days gestation) the effect of feeding and the diurnal variation was studied. Two studies (I and II) were made with an interval of 1 week where the hay ration $(18 \mathrm{~kg})$ were the same in both studies, but the concentrates given were 400 $\mathrm{g}$ in the first and $1200 \mathrm{~g}$ in the latter study. The ewes were fed with the same ration 1 week prior to each study. The hay was given at 9 a.m. and the concentrates at 3 p.m. Most of the hay was eaten during the first hours following feeding but some of it was eaten at other times during the $24 \mathrm{~h}$. The concentrates were consumed in about 10 $\min$.

\section{Blood samples}

Blood samples for studying the effects of pregnancy were drawn twice weekly (Monday and Thursday) during mid-and late pregnancy before morning feeding.

For studying the effects of feeding blood samples were drawn from the jugular vein 6 times during $24 \mathrm{~h}$, beginning $30 \mathrm{~min}$ before morning feeding, at 11 a.m., $30 \mathrm{~min}$ before feeding of the concentrates and at 4,8 and 12 p.m. Additional blood samples were taken the next day before morning feeding. Blood samples were collected in 2 different tubes: tubes containing sodium fluoride and heparin (Vacutainer) for glucose analysis and in tubes containing clot activator (Vacutainer) for insulin assay.

\section{Analyses}

Glucose was measured on Reaction Rate Analyser (LKB 8600, Bromma) by Gluc-DH method. The reagents were supplied by Merck, Darmstadt. Insulin was analyzed by a radioimmunoassay using a double antibody system. The insulin analysis was carried out by Statens Husdyrbrugsforsøg, Copenhagen.

\section{Results}

\section{Effects of pregnancy}

A reduction in insulin concentration was found as the pregnancy advanced (Fig. 1).

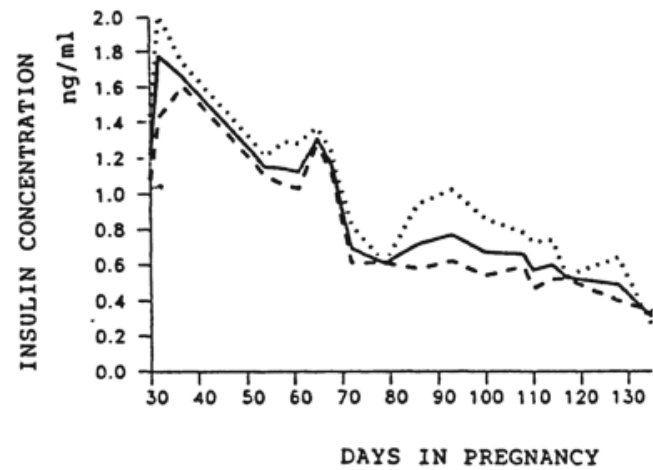

Figure 1. The concentration of insulin in the blood of 8 pregnant ewes presented as mean (__ $)$ and average for ewes carrying 1 (....) and 2 (----) fetuses. The number of ewes in each group is 3 and 5, respectively.

Concentration of insulin in the blood was significantly higher in mid pregnancy $\overline{\mathrm{x}}=1.5$ $\mathrm{ng} / \mathrm{ml}, \mathrm{SD}=0.62$ ) than in late pregnancy $(\overline{\mathrm{x}}=0.46 \mathrm{ng} / \mathrm{ml}, \mathrm{SD}=0.26)(\mathrm{p}<0.001)$. The average concentration of insulin in serum was significantly lower in twin-pregnant ewes than in ewes pregnant with 1 fetus $(\mathrm{p}<0.01)$.

Blood glucose fluctuated but during late pregnancy blood glucose level was significantly lower in twin-pregnant ewes (Fig. 2).

\section{Effects of feeding}

The study of feed-induced effect was carried out during $24 \mathrm{~h}$ in late pregnancy. In both studies (I and II) no increase in insulin con- 


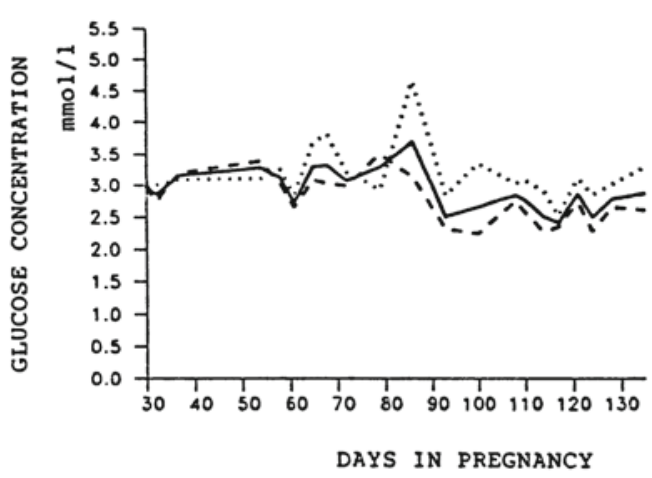

Figure 2. The concentration of glucose in the blood of 8 pregnant ewes presented as mean (__ and average for ewes carrying 1 (....) and 2 (----) fetuses. The number of ewes in each group is 3 and 5 , respectively.

centration was demonstrated in twin-pregnant ewes after feeding with hay, on the contrary an increase was found in ewes pregnant with 1 fetus (Fig. 3). The insulin concentration in blood of ewes pregnant with 1 fetus rose a little in study I after the ewes had consumed the concentrates, but no increase was observed in the blood of twin-pregnant ewes. In study II (Fig. 3) no such effect was observed in neither group of the pregnant animals. During a starvation period carried out three weeks after study II, two of the twin-pregnant ewes developed symptoms of pregnancy disease. Significantly lower mean insulin concentrations was found in the blood of these 2 animals throughout the day, than in the other twin-pregnant ewes that did not develop symptoms of the disease. In study I the average insulin concentration in the blood of these 2 ewes was $0.34 \mathrm{ng} / \mathrm{ml}$ $(\mathrm{SD}=0.05)$, but in the blood of the other twin-pregnant ewes that later did not develop symptoms of the disease the insulin concentration was $0.53 \mathrm{ng} / \mathrm{ml}(\mathrm{SD}=0.07)$. In study II the average concentration was 0.34 $\mathrm{ng} / \mathrm{ml} \quad(\mathrm{SD}=0.09)$ and $0.56 \mathrm{ng} / \mathrm{ml}$ $(\mathrm{SD}=0.11)$, respectively. In Table 1 the effects of feeding on the glucose concentration
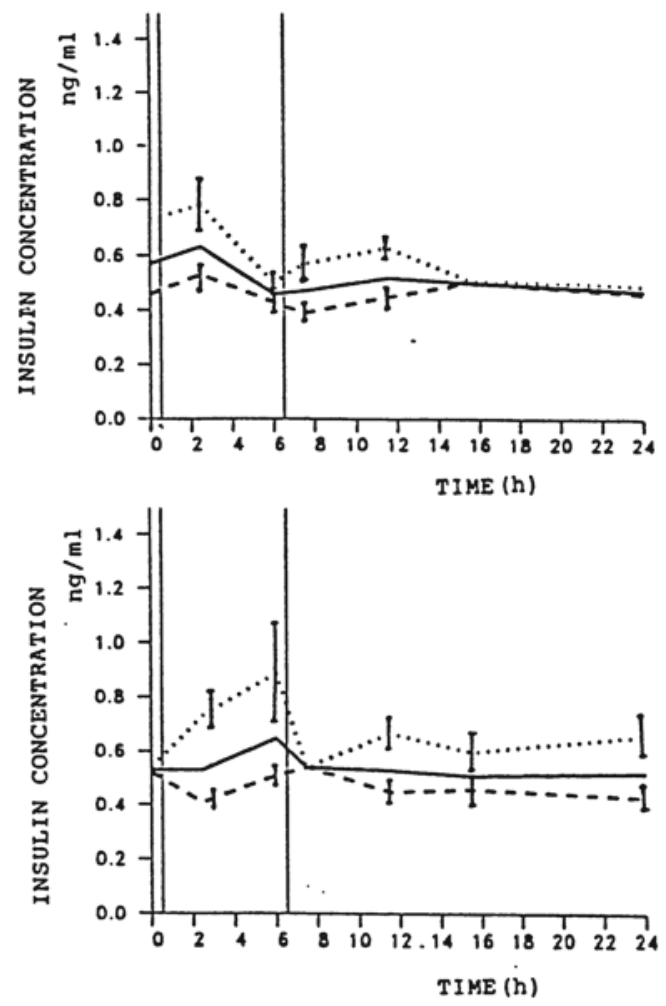

Figure 3. Diurnal variation in insulin concentration in the blood of 8 pregnant ewes (_ sents study I and Fig. 3b study II. Average observations from ewes carrying 1 (....) and 2 (---.) fetuses are presented. The number of ewes in each group is 3 and 5, respectively. The reference lines on $\mathrm{x}$-axis 0.5 and 6.5 shows the feeding time for hay and concentrates, respectively. Vertical bars indicate standard errors of mean (S.E.M.).

is shown. A limited effect is observed, especially if compared to the reference range based on approximately 80 healthy pregnant ewes in 4 herds of the same breed in the last month of pregnancy $(2.37-3.79 \mathrm{mmol} / \mathrm{l})$. Though an increased glucose concentration in the blood is observed after feeding with hay.

In both studies a positive correlation was obtained between the concentration of glucose 
Table 1. Changes in mean concentrations of glucose during the day in eight pregnant ewes in late pregnancy.

\begin{tabular}{lll}
\hline $\begin{array}{l}\text { Times of blood } \\
\text { sampling }\end{array}$ & $\begin{array}{l}\text { Study I } \\
\text { mmol/1 }\end{array}$ & $\begin{array}{l}\text { Study II } \\
\text { mmol/1 }\end{array}$ \\
\hline 08.30 a.m. & $2.77 \pm 0.35^{*}$ & $2.42 \pm 0.35^{*}$ \\
11.00 a.m. & $2.98 \pm 0.30$ & $2.51 \pm 0.39$ \\
02.30 p.m. & $2.33 \pm 0.25$ & $2.85 \pm 0.32$ \\
04.00 p.m. & $2.53 \pm 0.28$ & $2.83 \pm 0.22$ \\
08.00 p.m. & $2.57 \pm 0.24$ & $2.99 \pm 0.36$ \\
12.00 p.m. & $2.71 \pm 0.32$ & $2.95 \pm 0.35$ \\
\hline
\end{tabular}

*SD: standard deviation

and insulin in the blood of the ewes, $\mathrm{r}=$ $0.647,(\mathrm{p}<0.001)$ and $\mathrm{r}=0.477(\mathrm{p}<0.001)$, respectively.

\section{Discussion}

A reduction in insulin concentration is observed as the pregnancy advanced and most in twin-pregnant ewes. A similar observation of animals fed with a maintenance ration sufficient for nonpregnant ewes was made by Blom et al. (1976) the last 5 weeks towards lambing. In the present study the ewes should have obtained adequate nutrition according to the feeding plan, but the insulin concentration in the blood decreased steadily during both mid- and late pregnancy. The concentration levels of insulin in serum in late pregnancy are similar to that observed by Hove et al. (1976). It is evident from the present study that 2 fetuses increase the strain on the maternal carbohydrate metabolism resulting in a lower glucose concentration and a lower insulin concentration in twin-pregnant ewes in late pregnancy.

The study of feed-induced effects on glucose and insulin concentration demonstrated no increase in insulin concentration in twinpregnant ewes. Bassett (1974) observed an increase in serum insulin concentration after feeding in nonpregnant ewes, which were 50-
$100 \%$ greater than prefeeding values. A similar observation was made by Horino et al. (1968) and Trenkle (1970, 1971). Trenkle (1970) found that the effects of hay or grain diets on serum insulin levels was related to the effects of the diets on relative amount of individual VFA (votile fatty acids) in the rumen. Bassett et al. (1971) however showed that insulin levels were more closely related to the amount of protein digested in the intestines than to ruminal production of any individual VFA. In the present work no increase in insulin concentration was observed after feeding with hay or concentrates in twin-pregnant ewes in late pregnancy. Hove $\&$ Halse (1978) observed a similar absence of feed-induced increase in insulin concentrations in ketonaemic cows where glucose concentrations in the blood were simultaneously low. Hart et al. (1975) found that low initial insulin concentrations in cows corresponded to small insulin increments in response to feeding. In the present study similar observations were made in twin-pregnant ewes where both glucose and insulin concentrations were lower in twin-pregnant ewes than in ewes pregnant with 1 fetus. In 2 of those ewes that later developed symptoms of pregnancy disease during a starvation period a lower mean insulin concentration was found throughout the day, which could indicate that insulin status is of importance in the pathogenesis of pregnancy disease.

A positive correlation was obtained between the concentration of glucose and insulin in the blood in the present work. Similar observations have been made between the glucose entry rate and plasma insulin in ewes (Bassett et al. 1971) and between plasma insulin and glucose levels in lactating cows (Hove 1974, Schwalm et al. 1976). It is evident from the present study that 2 fetuses increase the strain on the maternal carbohydrate metabolism and the absence of a feed-induced 
insulin secretion in twin-pregnant ewes seemingly is to spare glucose. Low insulin levels and a low feed-induced response in twin pregnant ewes could indicate that the ewes have changed the metabolism to carbohydrate sparing metabolism by reducing glucose utilization in peripheral tissues and by stimulating the gluconeogenesis.

\section{Acknowledgements}

This work was supported by The Icelandic Science Foundation. I whish to thank all the members of the Clinical Central Laboratory and the Department of Internal Medicine, Royal Veterinary and Agricultural University, Copenhagen for their contribution. Further I would like to thank Statens Husdyrbrugforsøg, Copenhagen for carrying out the insulin analysis.

\section{References}

Bassett JM, Weston RH, Hogan JP: Dietary regulation of plasma insulin and growth hormone concentration in sheep. Aust. J. Biol. Sci. 1971, 24, 321-330.

Bassett JM: Diurnal patterns of plasma insulin, growth hormone, corticosteroid and metabolite concentrations in fed and fasted sheep. Aust. J. Biol. Sci. 1974, 27, 167-181.

Blom AK, Hove K, Nedkvitne JJ: Plasma insulin and growth hormone concentrations in pregnant sheep. II. Acta Endocr. Copenhagen. 1976, 82, 553-560.

Hart IG, Bines IA, Batch CC, Cowie A-T: Hormone and metabolite differences between lactating beef and dairy cattle. Life Sci. 1975, 16, 12851292.

Horino M, Machlin LJ, Hertelendy F, Kipnis DM: Effect of short chain fatty acids on plasma insulin in ruminant and non ruminant species. Endocr. $1968,83,118-128$.
Hove $K$ : Nocturnal plasma insulin in cows with varying levels of plasma ketone bodies: relation to plasma sugar and acetoacetate. Acta endocr. Copenhagen 1974, 76, 513-524.

Hove $K$, Blom AK: Plasma insulin and growth hormone concentrations in pregnant sheep I: Diurnal variations in mid- and late pregnancy. Acta Endocr. Copenhagen 1976, 82, 544-552.

Hove $K$, Halse $K$ : Absence of feeding-induced variations in plasma insulin in hypoglycaemic ketonaemic cows. Acta vet. scand. 1978, 19, 216-228.

Schwalm JM, Schultz LH: Relationship of insulin concentration to blood metabolites in dairy cow. J Dairy Sci. 1976, 59, 255-261.

Trenkle A: Effects of short-chain fatty acids, feeding, fasting and the type of diet on plasma insulin levels in sheep. J. Nutr. 1970, 100, 1323.

Trenkle A: Postprandial changes in insulin secretion rates in sheep. J. Nutr. 1971, 101, 1099.

\begin{abstract}
Sammendrag
Draegtighedens og fodringens indflydelse pả koncentrationen af insulin og glukose i blodet hos højdrægtige fär.

Drægtighedens og fodringens indflydelse på insulin og glukose hos 8 forsøgsfảr pá normal fodring blev studeret. Der blev registreret et tydeligt fald i blodets insulinkoncentration, efterhånden som drægtigheden skred frem. Glukosekoncentrationen i blodet hos fårene varierede meget, men i den sidste del af drægtigheden fandtes forskelle i glukosekoncentrationen i blodet, hvor glukoseindholdet i blodet hos tvillingdrægtige får var lavest. Der kunne ikke måles en forøgelse af insulinkoncentrationen efter en foderoptagelse hos de tvillingdrægtige får i modsætning til får med et enkelt foster. Fodringens indflydelse på glukosekoncentrationen var minimal, specielt $\mathrm{i}$ forhold til referenceomrádet. Der fandtes en positiv sammenhæng mellem koncentrationen af insulin og glukose i blodet.
\end{abstract}

(Received February 19, 1988).

Reprints may be requested from: Helgi Sigurdsson, Institute for Experimental Pathology, University of Iceland, P. O. Box 8540, IS-128 Reykjavik, Iceland. 
